\title{
THE CONCEPT OF SOFT VIOLENCE IN CRITICAL SECURITY STUDIES
}

\author{
Candyce Kelshall, President - Canadian Association for Security and \\ Intelligence Studies Vancouver, Canada
}
Natalie Archutowski, Executive Officer-Canadian Centre for Identity Based Conflict, Canada

Disclaimer: This briefing note contains the encapsulation of views presented by the speakers and does not exclusively represent the views of the Canadian Association for Security and Intelligence Studies.

\section{Key Events}

On September 16, 2021, Professor Candyce Kelshall and Ms. Natalie Archutowski presented on the Concept of Soft Violence in Critical Security Studies at the 2021 CASIS Vancouver Defence and Security Advisory Network online forum. Primary topics included: evaluating violence as soft in nature, how and where soft violence might fit in the realm of critical security studies, violent transnational social movements (VTSMs), sharp power, and soft power.

\section{Nature of Discussion}

The presentation provided an understanding of soft violence, soft power, sharp power, and how they intersect and differ. Professor Kelshall and Ms. Archutowski also expanded on the weaponization of soft violence by VTSMs and approaches to security identity.

\section{Background}

Professor Kelshall and Ms. Archutowski began the presentation by defining soft violence as "actions which fall short of criminally identifiable physical violence against members of an outgroup", often not qualifying as a hate crime because "hate words may not be exchanged or used" (Kelshall \& Neal, 2019). Soft violence might also be considered non-kinetic actions taken by those who identify with VTSMs. These movements seek to assert the superiority of one group over another, often without actual kinetic impact, which is used to damage the $f$ abric of society by impacting social cohesion (Kelshall, 2019).

Professor Kelshall and Ms. Archutowsi referenced Peterson (1992) who's academic article examined feminism in the context of international relations, 
stating that our understandings of the world are intrinsically shaped by gendered ontologies and epistemologies and thus suggest that soft violence could be examined within the critical security studies space with the feminist and poststructural perspectives.

Soft violence might be observed in the same fashion as gendered disparity whereby the white western systemic norms are perceived as superior to feminine oppressed colonised cultures and identities, making one set of traits viewed as more desirable than the other. Professor Kelshall and Ms. Archutowski go on to reference Himmel and Baptista (2016) whose study examined how national identity was represented in relation to their gender identity, stating that binary gender norms appear to shape respondents' representations of national identity. These norms shape how national identity is represented and must be taken into account as a contributing factor in understanding how identities are perceived. Through this understanding the speakers suggest that soft violence is a gendered expression used against those who are traditionally perceived as 'soft' relative to the perpetrator's own perception of self as dominant.

Those using soft violence are groups such as VTSMs, who seek to maintain and preserve perceived inherent dominance, legitimacy, superiority, and authority (Kelshall, 2021). These groups are distinct from other social movements due to the fact that while they are polycentric, reticulate, and segmentary, they are also identity exclusive and participation is based on a belief that certain aspects of life, which have social or cultural importance, are under a perceived threat (Kelshall \& Dittmar, 2018). VTSMs use soft violence to hold onto or manifest a social structure which allows their perceptions, norms, beliefs, and values to stay intact (Kelshall, 2021). This may be followed by kinetic violence to preserve and protect perceived positions of inherent structural power. Professor Kelshall and Ms. Archutowski suggest these groups can be observed using a gendered approach, whereby soft violence as expressed by VTSMs is always muscular, masculine, strong, aggressive, and warrior-like-waged against those less entitled.

This was followed by the discussion of soft war which is a concept of operations (CONOPS) to achieve dominance whereby soft violence is the ammunition used to achieve CONOPS. As soft war is transnational in nature, states can use soft violence to wage soft war against other states as a means of wielding sharp power which is coercive, and propaganda based. Sharp power is designed to deliver a sense of vulnerability or inferiority to another state and can be seen as a weapon when looking at tactics such as misinformation, disinformation, troll factories, or alternative truths. 
Professor Kelshall and Ms. Archutowski make the distinction between sharp power and soft power by which soft power can be seen when one state seeks dominance in the international system without being coercive. It can be seen as an expression of existing dominant systemic institutional power whose impact is influence over discourse, culture, and economic norms. The speakers found that there is an inverse relationship between soft power and soft violence stating that the greater soft violence the weaker the perception of retained or maintained soft power, likewise the softer the power the less likely that coercive power is used. Soft power can be used by states to wage soft war (influence) by using soft power (cultural dominance); to wage sharp power (target states with propaganda messaging); and as proxy warfare (mis/disinformation to divide and polarize)

To conclude their presentation, Professor Kelshall and Ms. Archutowski brought up the notion that polarization, the rise of extremism, and social and economic change, as well as the rise of some underdeveloped nations has created a crisis of identity within the international system. During this time transnational identities are fighting to maintain their position in the international system whilst emergent, subaltern, and oppressed identities are now benefitting from the power of the internet and social movements, and Generation $Z$ content creators who are redefining access, equity, and relationships between identities. This brings up their observations that perceptions around nationhood, race, and religion are arguably a feminist and critical security problem for the future. The acceptance of superior and inferior identities modelled on power and dominance in the international system could be said to be increasingly rejected as inadequate by people around the world. In fact, a post-structural or post-modern gaze might change the shape of security as we know it.

\section{Key Points of Discussion}

- It is possible to examine soft violence within the critical security studies space by incorporating social and political theory dealing with emergent security problems within the realm of feminist and post-structural perspectives.

- VTSMs often use soft violence to assert and maintain existing social structures that allow their perceptions, norms, beliefs, and values to be dominant over others. These groups can be observed using a gendered approach, whereby soft violence, as expressed by VTSMs, is always muscular, masculine, strong, aggressive, and warrior-like waged against those less entitled.

- Soft war is a concept of operations to achieve dominance, whereby soft violence is the ammunition used to achieve CONOPS based on the theatre of 
operations. States can use soft violence to wage soft war against other states as a means of wielding sharp power which is coercive, and propaganda based.

- There is an inverse relationship between soft power and soft violence. The greater soft violence the weaker the perception of retained or maintained soft power; the softer the power the less likely coercive power will be used.

- Soft power can be used by states to wage soft war (influence) by using soft power (cultural dominance); to wage sharp power (target states with propaganda messaging); and as proxy warfare (mis/disinformation to divide and polarize).

\section{Critical Thinking Question}

- Soft violence can come in many forms - so arguably, are everyday citizens perpetrating fifth generation warfare (knowingly or unknowingly) movements to create far-right ideological appeal in mainstream circles?

\section{Key Terms}

Soft Violence: “Actions which fall short of criminally identifiable physical violence. Soft violence often does not meet the threshold of a hate crime, as hate words may not be exchanged or used" (Kelshall \& Neal, 2019). It takes the form of culturally nuanced inexplicit cues which are injurious by implying and reinforcing perceived power disparities. Soft violence might also be considered non kinetic actions taken by those who identify with identity based social movements which entrench or highlight the superiority of one group over another without actual kinetic impact (Kelshall, 2019).

Soft War: includes all non-kinetic measures whether persuasive or coercive including practices such as: cyber warfare, economic sanctions, trade wars, media warfare, propaganda, civil discord, etc. (Gross \& Meisels, 2017)

Violent Transnational Social Movements VTSMs: While all social movements are polycentric, reticulate and segmentary, Violent transnational Social Movements (VTSMs) are primarily extremist in nature, violent in expression and identity exclusive (Kelshall, 2021). They transcend state boundaries to unite individuals - predisposed to violence which may be soft or kinetic - with shared ideologies, perspectives or grievances particular to identity (Kelshall, 2021). 


\section{Further Readings}

Critical security studies: An introduction. (2nd ed.) (2014) by Columba Peoples and Nick Vaughan-Williams.

https://doi.org/10.4324/9780203764237

Soft violence, social radicalisation, and violent transnational social movements (VTSMs). The Journal of Intelligence, Conflict, and Warfare, 3(3), 146-153 (2021) by Candyce Kelshall.

https://doi.org/10.21810/jicw.v3i3.2800

Violent transnational social movements and their impact on contemporary social conflict. The Journal of Intelligence, Conflict, and Warfare, 1(3), 20 (2019) by Candyce Kelshall.

https://doi.org/10.21810/jicw.v1i3.840 


\section{References}

Gross, M. L., Meisels, T., Walzer, M., \& Wolfendale, J. (2017). Soft war: The ethics of unarmed conflict. Cambridge University Press.

Himmel, R., \& Baptista, M. (2016). Gender norms and national identity representation: An exploratory data analysis. https://mariamanuelbaptista.com/pdf/VCIEC_eng_540_547.pdf

Kelshall, C. M., \& Dittmar, V. (2018). Accidental power: How non-state actors hijacked legitimacy and re-shaped the international system. Simon Fraser University Library.

Kelshall, C. (2019). Violent transnational social movements and their impact on contemporary social conflict. The Journal of Intelligence, Conflict, and Warfare, 1(3), 20. https://doi.org/10.21810/jicw.v1i3.840

Kelshall, C. M., \& Neal, P. (2019). Pinehurst. Unpublished Manuscript.

Kelshall, C. (2021). Soft violence, social radicalisation, and violent transnational social movements (VTSMs). The Journal of Intelligence, Conflict, and Warfare, 3(3), 146-153.

https://doi.org/10.21810/jicw.v3i3.2800

Peterson, V. S. (1992). Transgressing boundaries: Theories of knowledge, gender and international relations. Millennium: Journal of International Studies, 21(2), 183-206.

https://doi.org/10.1177/03058298920210020401

\section{(9) $\odot \Theta \Theta$}

This work is licensed under a Creative Commons Attribution-NonCommercial-NoDerivatives 4.0 International License.

(C) (CANDYCE KELSHALL \& NATALIE ARCHUTOWSKI, 2021)

Published by the Journal of Intelligence, Conflict, and Warfare and Simon Fraser University

Available from: https://jicw.org/ 